Kateřina Kubenková

\title{
MUNICIPALITY AND INCOME TAX
}

\begin{abstract}
This article is a brief insight into the issue of income tax and its relation to the municipalities. Firstly, the Authors present some basic information about the income tax and the new Act on the Income Tax. Further, budgets of municipalities are described, where attention is focused especially on the revenues of municipalities from the income tax. Besides a historical development of the amount of this revenue and its present amount, the Authors also propose different ways how municipality could influence the amount of revenues which flow from the income tax into its budget. Conclusion summarizes facts about instruments which are in competence of municipality, for law rules taxes very strictly.
\end{abstract}

\section{Key words}

Municipality; income tax; budget; tax revenues

\section{Introduction}

Within the amendment of the Act No. 586/1992 Coll., on the Income Tax with effect from 1 January 2017 we would like to focus on relation between this tax and local self-government unit, especially municipality - from the preview of the current situation to possible future development. We will be interested also in methods which municipality can use to influence the amount of income tax yield - percentage as well as the number of taxpayers in the municipality - flowing into its budget.

This tax relates to direct taxes and the Act on Income Tax divides it into personal income tax and corporate income tax. It is a part of the municipality's income. The Act No. 243/2000 Coll., on the budget determination of revenues from specific taxes to territorial self-governing units and specific state funds declares percentage amount which is delivered to the concrete budget, for example of municipality or region. Municipality gains from taxes yield from property tax, value added tax and at last from the income tax. Local charges can also be included into tax revenues. We could mentioned, for example dog charge, charge for spa and recreation stay, charge for using public places, charge on entrance, etc.

Among other revenues we could distinguish revenues from self-employment, gifts, revenues from sale of fixed assets or from sale of shares. The last and very important part of all incomes are donations, whether from the state or regional budget. Therefore, income tax shows how many percent the subject participates in creating the municipality budget due to subject's income, instead of excise duties. Budgetary determination of taxes is essential for municipality and it creates a large part of its revenues.

\section{Budget of a municipality}

A budget is a financial plan, which manages funding of the municipality activities. It is created for the following year and is based on budget forecast, which contains intended revenues and expenditures of a municipality. Revenues of a municipality include disposal of property, municipal activity, grants, tax yield and others [Act No. 250/2000 Coll.]. The largest part of the revenues is composed of tax and grant revenues. Although non-tax revenues are not as great as tax revenues [Tomášková, Pařízková 2015]. Expenditures involve performance of obligations resulting from law, contracts, expenditure on its own activity, etc. 
There is nothing specific about budgetary process during the construction of a budget. Draft budget has to be published at least for 15 days on a notice board - it is a manifestation of the transparency principle. Afterwards, the draft is discussed at the local council and then approved. Otherwise municipality proceeds according to the budget for the prior period. However, this is not the end of the budgetary process, because its part is also management in accordance with the plan and continuous and consequent control [Act No. 250/2000 Coll.].

\section{Income tax as a revenue of the municipal budget}

Tax revenues of the municipality can occur as local taxes, entrusted taxes, shared taxes, or such taxes, which are collected besides the central taxes [Provazníková 2015]. We will be interested only in entrusted and shared taxes, which are related to income tax. Revenue from entrusted taxes belongs in this case entirely to the municipality. It includes a property tax, which is unfortunately only additional source of revenues of the municipal budgets [Radvan 2011], and personal income tax from self-employment and business. Only $30 \%$ of this tax flows to the municipal budget and it is always the municipality in which the entrepreneurs have their permanent residence. On the other hand, shared taxes have similar tax base, which is shared by the state, regions and municipalities. Collected taxes are shared in accordance with the law and municipalities have no actual chance to influence it. There are two types:

- derivative type - is based on distributing the percentage, which belongs to municipalities, according to the revenue from this tax on the territory of the municipality;

- non-derivative type - there is a distribution based on criteria other than the tax revenue on the territory, for example according to the number of residents of a community. The Czech Republic uses this method.

In the Czech Republic these taxes include a part of personal income tax from self-employment and business, personal income tax from employment, corporate income tax and value added tax [Provazníková 2015]. The amount of tax revenues percentage cannot be influence by municipality - percentage is regulated by the law. However, the municipality can influence the number of inhabitants, for example by creating appropriate environment for families with children or for business entities. All this has an impact on the amount of the revenue which municipality obtains.

\section{Budget composition}

Budget composition determinates uniform division of fiscal operations, which is obligatory for all public budgets including municipal budgets [Provazníková 2015]. It allows comparison of special, i.e. between individual budgets on the same level, and also temporal domain, between different periods. It ensures unity and transparency throughout the whole budget system. Using this we can far better analyse the economy and cover the budget deficit. The problematics is regulated by the regulation of the Ministry of Finance No. 323/2002 Sb., o rozpočtové skladbě (on budget composition) [Provazníková 2015].

The budget composition uses four basic perspectives sorting fiscal operations: chapter, generic, sectoral and consolidation [Červenka 2009]. The generic perspective is considered basic and it is obligatory for the municipal authorities. Using this we can differentiate between fiscal operations of revenue, expense and the so-called funding. Tax revenues are using this perspective defined as compulsory, unreciprocated, irretrievably collected revenue, coming from taxes, insured social and health insurance and supplementary payments including taxes and penalties for late or incorrect payment [Provazníková 2015]. Among these revenues are ranked income, profit and capital gains tax and also taxes on domestic goods and services, goods and charges on chosen activities and others.

\section{Developement of tax revenues}

Tax revenues are one of the most important municipal revenues in the Czech Republic, because they make almost half of their total amount. Because of this, it is appropriate to become familiar with the development of tax revenues since the origin of the Czech Republic, due to implementation of a new tax system. The development can be divided into three phases (based on break-through moments) [Provazníková 2015].

Phase I (1993-1995): By the introduction of a new tax system the individual income tax (IIT) became the source of municipal revenues - the municipality gained the whole income from the IIT from self-employment and a share on IIT from dependent activity. A few years later the revenues were extended by the whole income from the corporate income tax, but it had only trivial significance. At the time bonding tax revenues with district-wide revenues made significant problems. It caused great differences in municipal revenues in the different districts. It was not uncommon that two municipalities of almost the same characteristics gained different level of tax revenues 
only by being located in different districts. There were also speculative practices of municipalities and their acquisition of businesspeople permanent residence. Due to this fact, the passage of the amendment to the budget rules was imminent.

Phase II (1996-2000): The amendment of 1996 brought changes focused mainly on the individual income tax from dependent activity and the corporate income tax. The goal was to connect tax revenues of municipalities with economic activities of the businesspeople operating on the municipality's territory and to avoid widening the differences between municipalities and districts [Provazníková 2015]. This amendment did not remove unequal tax revenues of the municipalities within the territory for the future. Above all small municipalities were weaker due to not having the payers' residence. Competition for acquisition of businesspeople also prevailed [Provazníková 2015].

Phase III (2001-present): It was more than desirable to pass another amendment removing sources of unequal differences in the municipal revenues and cutting the bond with the district-wide revenues. There were also efforts to contribute to greater stability of the municipal budgets in time and to better predictability of the municipal budgets using bigger involvement of the shared taxes. Also constantly raising unequal dynamics in the development of tax revenues of the municipal budgets and the state budget was removed. Concurrently it was necessary to include new level of a higher territorial self-governing unit, kraj (region), in the funding [Provazníková 2015]. In 2002 was assigned new motivational element to the municipalities, $1.5 \%$ share of the republic-wide revenues from the individual income tax from dependent activity and functional benefits depending on the number of employees in the municipality (in comparison to the total number of employees in the Czech Republic). In 2008 the legislation was changed once more. This time after fierce demonstrations followed by submission of the complaint to the Constitutional Court against discrimination of small municipalities anchored in the Act No. 243/2000 $\mathrm{Sb}$. In the following amendment were introduced new criteria for the redistribution of the revenues from the shared taxes for the municipalities: criterion of total acreage of the municipality, criterion of a simple number of residents of the municipality and modified existing criterion - number of residents of the municipality modified by coefficients of size categories of the municipalities. Municipality revenues were increased to the $21.4 \%$ share of the shared taxes revenues [Provazníková 2015].

\section{The present day}

Currently, the concerned problematics is adjusted by the Act No. 243/2000 Sb., on the budget determination of revenues from specific taxes to territorial self-governing units and specific state funds - the BDT. Tax revenues are transferred to the municipal budgets by the tax administrator once every month, unless specified otherwise [www. financnisprava.cz/cs/dane-a-pojistne/kraje-a-obce/ danove-prijmy-kraju-a-obci/danove-prijmy-rozpoctu-kraju-a-obci-3736 (accessed 10.02.2017)]. The specific amount of money to be assigned to the municipalities is calculated using a mechanism specified in $\$ 4$ of the BTD. The basis for the calculation of municipality's claim is 100 $\%$ of national gross tax revenue. There are exceptions, for example for the individual income tax there is a basis of $60 \%$ (except for the tax from dependent activity and for the taxes collected by the reduction by a special rate) [www.financnisprava.cz/cs/dane-a-pojistne/krajea-obce/danove-prijmy-kraju-a-obci/danove-prijmy-rozpoctu-kraju-a-obci-3736 (accessed 10.02.2017)].

From the basis specified in the preceding paragraph according to the BTD a specific percent is determined to be the final complex for the calculation of municipalities' claim in the Czech Republic. The rest of the tax revenue falls to the state budget and to the regional budgets. The rate which a specific municipality gains from the final complex comes from the criteria based on:

1. total acreage of the municipality - criterion weight $3 \%$

2. simple number of residents - criterion weight $10 \%$

3. number of learners - criterion weight $7 \%$

4. number of residents modified by coefficients of gradual transitions between size categories of the municipalities - criterion weight $80 \%$

So final percentage is determined by the division of the criteria for the specific municipality and the summary of the criteria for all municipalities. Exception is made for four largest cities of the Czech Republic - Brno, Ostrava, Plzeň and Prague - for which special rules are applied.

Of 1 January 2017 the problematic, and for the most of municipalities disadvantageous, $30 \%$ share from corporate taxes (the so-called motivational element) was removed by the senate amendment [www.dvs.cz/clanek.as$\mathrm{p}$ ? id=6710577 (accessed 10.02.2017)] and in contrast the share of municipalities on VAT was raised to the total of $21.4 \%$. The approved text is a great benefit to the municipalities. According to preliminary estimates over 5.500 municipalities should gain more than CZK 1 billion extra in total. The following reasons supported the removal of the motivational element: 
- This share favoured only a small group of municipalities, not always totally objectively

- Only $23 \%$ of the municipalities of the Czech Republic had claim on the share

- Income from this tax is decreasing in the long term, plus it is hard to predict

\section{Possibilities to influence the income tax of municipalities}

\section{Indirect influence of municipalities}

To implement the solution to raise community revenues from the income tax is more in the competence of the state than the municipality itself. The easiest way to change it is by political decision providing higher tax rate to the municipalities. But municipalities cannot influence this, they can only propose to raise this tax. We could also think about increasing the number of criteria to determine the amount of a specific sum of nationwide tax yield - today we talk about the area of municipality, population and number of children who attend schools or other school facilities, which are established by the community. For example, the area of its cadastral territory could be tightened to a built-up area. This would help in more equitable allocation of tax yield. Also more criteria could better express the need of the municipality regarding its expenses. This topic will be discussed below.

If we leave this method and close it as a method which community cannot influence, we will demonstrate the minimal instruments belonging to municipality. As mentioned above, the specific sum which enters into the municipality account comes from legal criteria. We will attempt to describe each one separately and we will explain how municipality could use it for its own profit and whether it is possible to increase the number of residents considering income tax depending on them.

The first legal criterion is its area. It is determined by cadastral map limited by such other territories of neighboring villages. Their borders meet. Municipality could change only the size of its built-up area and therefore the relation between built-up area and non-urbanized area. In this case it has no significance.

Another important element is the number of residents who have their permanent residence there. It means not only factual place of residence but registered place of permanent residence, because income tax yield flows only to the municipality where the person's permanent residence is. Municipality could attract new inhabitants by creating better conditions for living and positive development for their children, and to increase the number of its residents modify parks, playgrounds. Also it is possible to create quiet areas for living, cheaper building sites for constructing new houses, ensuring good access to larger cities by public transport. Establishment of basic schools or kindergartens in the community is suitable for families with children for two reasons - first one is a closer accessibility without the need to commute and the second one is a stable team which works during school lessons as well as after school, near to their homes. Also construction of new local council flats belongs to the one of solutions - rent of these apartments is lower than of the apartments in possession of housing associations or privately owned apartments. For businesspeople municipality could offer non-residential premises for rent, cheap building sites, Construction Company residing right in the community - this all could make their businesses go easier. Last criterion is the number of pupils who go to schools or other school facilities established by municipality. There is only one possibility how municipality could influence this point - establish some of these school facilities with the highest possible number of pupils.

\section{Proposition of changes}

The above mentioned ideas show how a municipality may indirectly influence its tax revenues. In this chapter we try to propose suitable solutions for the shared taxes to be redistributed more fairly, eventually for the tax jurisdiction to be strengthened. The BDT could, besides a few present criteria used for the redistribution of the shared taxes (acreage of the municipality, number of residents, number of children and students attending schools established by the municipality, gradual transition), consider some other factors. It could inspire abroad, for example the legal regulation of the Slovak Republic considers the number of residents who exceeded the age of 60 . It could be used to estimate the expenses of the municipality on people in the retirement age [Kapounová 2009]. In addition, the distance to the administrative authorities, traffic availability, job opportunities, level of unemployment, or municipality's natural conditions could be also considered. The more criteria is examined, the more fair the redistribution of shared taxes to the individual municipalities is [Kapounová 2009].

Motivational elements are used by the legislators to motivate municipalities to create conditions beneficial to support business and employment in their area. It is the best way to increase their income from tax revenues. Till 1 January 2017 was a typical motivational element 30\% share from the business people's taxes, but it was removed 
due to the reasons stated above. Currently, the motivational element stays at $1.5 \%$ share of the national tax revenues of IIT from dependent activity according to the number of employees in the given municipality. It is important to motivate municipality to attempt to participate in its economic development and it is also necessary for the municipality to be for the effort financially rewarded [Kapounová 2009]. To increase the influence of the motivational elements, new elements could be introduced or at least the percentage share of the existing ones should be increased.

Additional taxes could be used for strengthening of municipality's tax jurisdiction, which is currently insignificant. It is not a new institute, it already appeared in Austria-Germany era and became municipality's main revenue. This tradition was continued in the newly founded Czechoslovak Republic [www.toulky-minulosti. $\mathrm{cz} /$ danove-prirazky (accessed 10.2.2017)]. It means that every municipality can set a supplementary charge to the centrally set taxes depending on its needs and deliberation. This is used in Denmark, where state-level taxes are at a low level and municipalities have the opportunity to choose their own rates. Similar solution is used in France, where similarly additional taxes can be set by municipalities and regions.

\section{Conclusion}

Present BDT does not give, in comparison with other developed countries, too much space for municipalities to influence their tax revenues. It is caused by the fact that all the taxes within the approved tax system are regulated by the laws with nationwide validity and are resolved by the parliament. Using these laws the basic parameters of the taxes are determined - the tax entity, tax object, tax basis and tax rate. In addition, all these taxes are collected by the state through the territorial fiscal authorities.

As it was stated above, the municipality cannot influence tax revenues. On the one hand, it decreases the expenses spent on the tax administration, and the other hand the bond between returned taxes and the expenses of the municipalities' budgets disappears. Also the bond between the taxpayers and the given area disappears, which often leads to unwillingness to pay taxes. After that these subjects have a tendency to evade taxes or to commit various tax frauds. Concurrently the interest of the public in the municipalities' budgets decreases and with that also the eventual public supervision over the economy of a specific municipality [Provazníková 2015].
In this contribution we outlined several possibilities how municipalities can at least indirectly influence their tax revenues and concurrently we tried to propose several solutions which can lead to strengthening the municipality's tax authority or at least to a better and more righteous shared tax redistribution.

\section{Bibliography}

Červenka M. (2009), Soustava veřejných rozpočtů, Leges, Praha

Kapounová A. (2009), Vliv daňových př́immů na financování obce [online]. Brno, Diplomová práce, pp. 66. Mendlova zemědělská a lesnická univerzita $\mathrm{v}$ Brně, provozně ekonomická fakulta (accessed 10.02.2017).

Provazníková R. (2015), Financování měst, obcí a regionů: teorie a praxe, Grada Publishing, Praha.

Radvan M. (2011), Vlastní daňové přímy obcí, Masarykova univerzita, Brno.

Tomášková E., Pařízková I. (2015), Veřejné finance - ekonomické souvislosti, Masarykova univerzita, Brno.

\section{Legal Acts}

Act No. 586/1992 Coll., on the Income Tax.

Act No. 250/2000 Coll., on budgetary rules of territorial budgets.

Act no. 243/2000 Coll., on the budget determination of revenues from specific taxes to territorial self-governing units and specific state funds.

\section{Internet sources}

Daňové prŕímy rozpočtů krajů a obcí dle zákona o rozpočtovém určení daní. Finanční správa [online], www. financnisprava.cz/cs/dane-a-pojistne/kraje-a-obce/ danove-prijmy-kraju-a-obci/danove-prijmy-rozpoctu-kraju-a-obci-3736 (accesed 10.02.2017).

Rozpočty obcí a krajů v roce 2016. Deník veřejné správy [online], www.dvs.cz/clanek.asp?id=6710577 (accesed 10.02.2017).

Daňové přirážky. Toulky minulostí [online], www.toulky -minulosti.cz/danove-prirazky (accessed 10.2.2017).

\section{Authors biographies:}

Nikola Chábová - Student, Faculty of Law at Masaryk University, Brno, the Czech Republic.

Kateřina Kubenková - Student, Faculty of Law at Masaryk University, Brno, the Czech Republic. 